\title{
Land uplift-driven shift of the outlet of Lake Ähtärinjärvi, western Finland
}

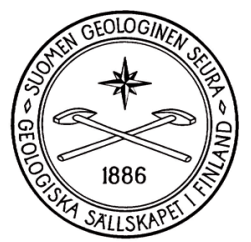

\author{
Heikki Seppä* 1) and Matti Tikkanen ${ }^{2)}$ \\ ${ }^{1)}$ Department of Geology, P.O. Box 64, FI-00014 University of Helsinki, Finland \\ 2) Department of Geography, P.O. Box 64, FI-00014, University of Helsinki, Finland
}

\begin{abstract}
Lake Ähtärinjärvi, at the northern end of the River Kokemäenjoki watercourse in northern central Finland, has been known to have an older outlet channel across the modern Suomenselkä watershed to the Bothnian Bay. The ancient connection over the watershed is indicated by the existence of a conspicuously deep and wide palaeochannel that runs from the northern end of Lake Ähtärinjärvi to the headwaters of the River Ähtävänjoki Radiocarbon datings of the basal sediments of the channel show that the flow in the old outlet channel ceased at about I500 cal yr BP; the old channel therefore functioned as an outlet since the isolation of the lake at about $9900 \mathrm{cal}$ yr BP to $1500 \mathrm{cal}$ yr BP. Sedimentological studies of Lake Ouluvesi, located below the modern outlet of the lake system, suggest opening of the modern outlet at $3200 \mathrm{cal}$ yr BP, indicating that the lake system had a 1700 year period of bifurcation before the final drying up of the old outlet channel. The reconstruction of the tilting of the lake level supports this pattern, and demonstrates further that during the early-Holocene the lake consisted of three basins located at different levels until the transgression caused by the tilting gradually brought the basins to the same level.
\end{abstract}

Key words: paleolimnology, lakes, uplifts, lake-level changes, transgression, outlets, paleochannels, Holocene, Lake Ähtärinjärvi, Finland

* Corresponding author email: heikki.seppa@helsinki.fi

\section{Introduction}

The maximum depth of the Fennoscandian ice sheet in northern Scandinavia has been estimated at about 2.6 kilometres (Siegert et al., 2001). The magnitude of the isostatic rebound following the melting of the ice sheet in the northern end of the Bothnian Bay has been about $800 \mathrm{~m}$, but only about $300 \mathrm{~m}$ in southeastern Finland (Balling, 1980; Mörner, 1980). The regional differences of the uplift rate and the resulting tilting of the landscape have caused shifts in the outlets in the Baltic Sea basin in central Sweden and the Danish Straits (Björck, 1995). The phenomenon has also influenced the development of the lake basins isolated from the Baltic Sea, either as transgressions or regressions, depending on the location of the outlet in relation to the direction of tilting. In many large lakes of Finland the tilting has resulted in shifts of the outlet, in some cases three times in the same lake (Hellaakoski, 1928; Saarnisto, 1970, 1971b; Tikkanen, 1990, 2002). Within the Baltic Sea region such shifts have been particularly typical in Fin- 
land where the general topography is flat, but they have been observed also in Sweden (Donner, 1995). In Finland about ten shifts of the outlet of large lakes are known, and they mostly date to 9500 to $5000 \mathrm{cal}$ yr BP (Saarnisto, 1971b; Tikkanen, 1992).

The most significant changes in the outlets of the Finnish lakes have taken place in the lake region of central Finland where all three major watercourses have had their outlets in the north-west, across the modern Suomenselkä watershed during the early Holocene. Lake Saimaa and Lake Päijänne drained through a common outlet to the headwaters of the present River Kalajoki (Tolvanen, 1926; Sauramo, 1940: Aario, 1965; Saarnisto, 1970, 1971a, 1971b; Ristaniemi, 1987) and Lake Näsijärvi to the headwaters of River Lapuanjoki (Tolvanen, 1924; Tikkanen \& Seppä, 2001). The differential land uplift rate caused the opening of the new outlets in the south, so that the new outlet of Lake Näsijärvi, the Tammerkoski Rapids, was initiated at $7500 \mathrm{cal}$ yr BP (Tikkanen \& Seppä, 2001), River Kymijoki, the modern outlet of Lake Päijänne, at 7000 cal yr BP, and River Vuoksi, the modern outlet of Lake Saimaa, at about 5700 cal yr BP (Saarnisto, 1970).

The development of most of the large lakes has been quite thoroughly studied, including the radiocarbon dating of the shifts of the outlets channels. There remains, however, one unstudied large lake, Lake Ähtärinjärvi, in the northern end of the River Kokemäenjoki watercourse, which has been known to have an older outlet channel across the modern Suomenselkä watershed to the present River Ähtävänjoki and to the Bothnian Bay (Vilkuna, 1951). The ancient connection over the watershed is indicated by the existence of a paludified channel which leads across the watershed and which is conspicuously deep and wide to have been formed by the minor rivulet flowing in the channel at present. As the modern threshold of this palaeochannel is only few metres above the level of Lake Ähtärinjärvi, Vilkuna (1951) assumed that the shift to the new outlet in the southern part of the lake must have taken place only a few hundred years ago. Apart from the topographic measurements of the old channel (Vilkuna, 1951), the post-glacial history of Lake Ähtärinjärvi has not been studied and the shifts of its outlet have not been dated. The aim of this study is to certify the existence of the old outlet channel over the modern watershed and to determine when and how the formation of the modern outlet in the southern part of the lake system took place.

\section{Study area and methods}

Lake Ähtärinjärvi is located in the northernmost part of the River Kokemäenjoki watercourse near the Suomenselkä watershed, in the municipalities of Ähtäri, Soini, and Lehtimäki (Fig. 1). The area of Lake Ähtärinjärvi proper is $45.1 \mathrm{~km}^{2}$ (Raatikainen $\& \mathrm{Ku}$ usisto, 1990) and its altitude is $153.5 \mathrm{~m}$ a.s.l. From the southern end of Lake Ähtärinjärvi proper the lake drains through a narrow Strait Ähtävänsalmi to Lake Välivesi and from there to Lake Hankavesi, again through the narrow Strait Näsinsalmi. Lake Välivesi and Lake Hankavesi are at the same level with Lake Ähtärinjärvi proper and these lakes have a common outlet, River Inhanjoki, from Lake Hankavesi to Lake Ouluvesi. The width of Lake Ähtärinjärvi proper is $1-3 \mathrm{~km}$ and the length $29 \mathrm{~km}$. The size of the catchment of Lake Ähtärinjärvi is $479.98 \mathrm{~km}^{2}$ and the size of the whole catchment of River Inhanjoki is 863.22 $\mathrm{km}^{2}$, of which about $10 \%$ is water (Ekholm, 1993). As Lake Välivesi and Lake Hankavesi are at the same level with Lake Ähtärinjärvi in this study they are considered as parts of Lake Ähtärinjärvi, giving a total length of $39 \mathrm{~km}$ for the whole lake system.

The average depth of Lake Ähtärinjärvi is $6,1 \mathrm{~m}$, maximum depth $28 \mathrm{~m}$, and the theoretical water residence time 1,8 years (Ähtärinjärvi-projekti 2004). Humans started to influence the surface level of the lake in the 1830s, when the outlet channel, River Inhanjoki, was dammed (Figs. 2 and 3). Water level regulation began in 1919, with the regulation amplitude of $1 \mathrm{~m}$. The present regulation amplitude is $1.65 \mathrm{~m}$ (152.76-154.41 m). The upper part of the River Inhanjoki has been channelled and the course of the original outlet channel has been marked in Figure 2 with dark shading. The original outlet channel started 


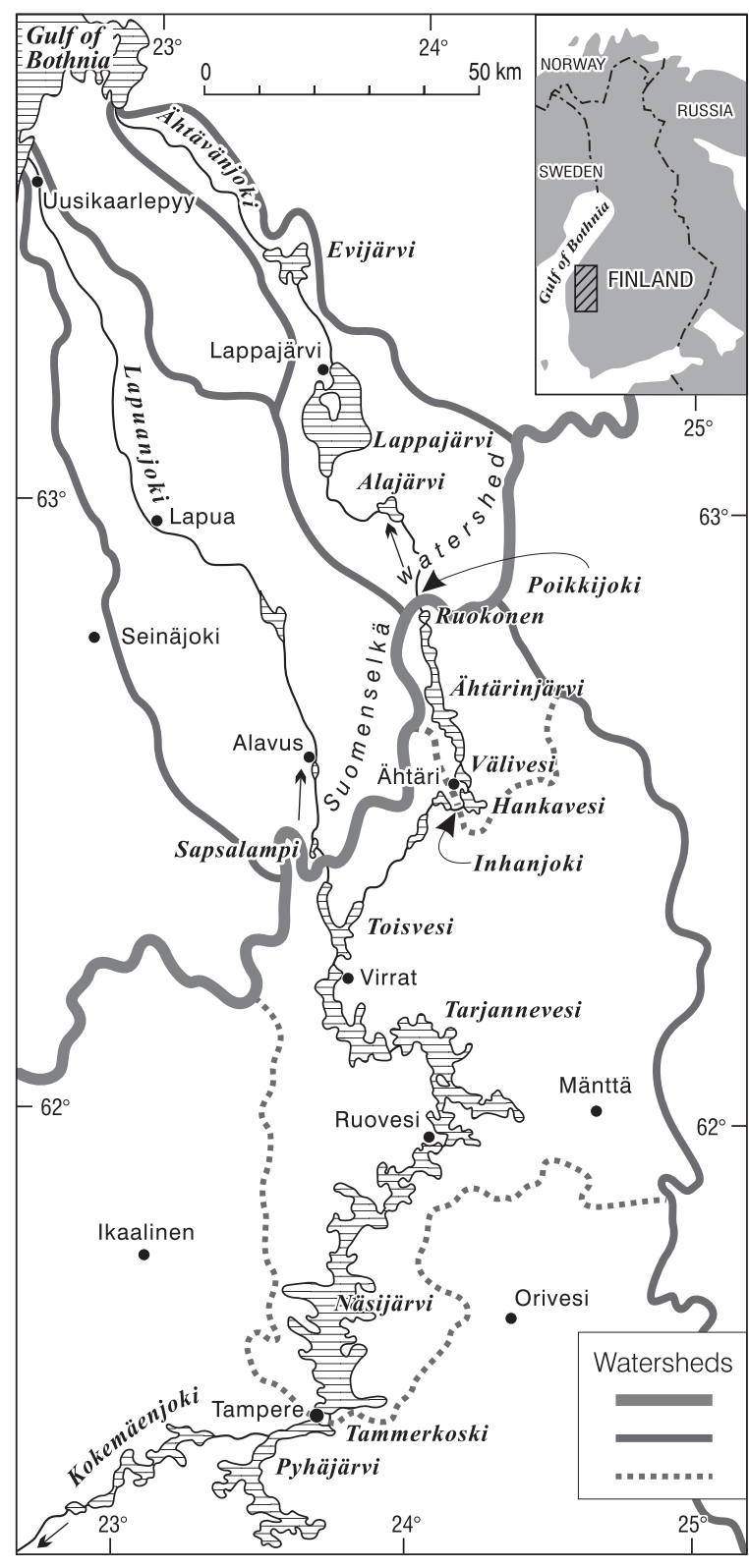

Fig. I. The location of Lake Ähtärinjärvi in the upper part of the River Kokemäenjoki catchment area. The old outlet channel over the modern watershed (Suomenselkä) is indicated with an arrow. As indicated in the map, Lake Näsijärvi, a larger lake to the south-west of Lake Ähtärinjärvi, also had a northern drainage channel over the modern Suomenselkä watershed until $7500 \mathrm{cal}$ yr BP (Tikkanen \& Seppä, 2002). At present both lakes drain to River Kokemäenjoki, south-west of Tampere.

as two branches, with an island in between. The soil of the outlet area is stony and bouldery till and the erosion of the channel has been slow and the chan- nel has remained shallow. The bottom of the channel below the regulation dam is over $2 \mathrm{~m}$ lower that than the surface of the lake (Fig. 3).

Lake Ähtärinjärvi is the highest lake of the Ähtärinreitti watercourse and its waters drain through River Inhanjoki to Lake Ouluvesi, $13.7 \mathrm{~m}$ below the level of Lake Ähtärinjärvi, and from there through River Hyvösenjoki to Lake Peränne. From there the flow continues to Lake Toisvesi which was part of the ancient Lake Näsijärvi during the period when this lake drained to the north to River Lapuanjoki (Tikkanen \& Seppä, 2001). Despite its high altitude, Lake Ähtärinjärvi was submerged by the Baltic Sea during the regional deglaciation which took place at about 10500 cal yr BP (Rainio \& Johansson, 2004). A little before the withdrawal of the ice sheet margin the Ancylus Lake stage had begun (Saarnisto, 2000; Tikkanen \& Oksanen, 2002). The highest shoreline of Ancylus Lake is located at an altitude of $180 \mathrm{~m}$ a.s.l. in the southern part of the lake and at $200 \mathrm{~m}$ a.s.l. in the northern part of the lake (Eronen 1990, 2005), implying that the water level was about $25-25 \mathrm{~m}$ above the present surface of Lake Ähtärinjärvi. North of the modern lake there was a large supra-aquatic highland. In addition, the peaks of the Suokonmäki hill (294.0 $\mathrm{m}$ ) and Ukonmäki hill in the northern part of the basin were above the water level. Due to the rapid isostatic uplift the water level sank despite the transgression of Ancylus Lake at about 10500 to $10000 \mathrm{cal} \mathrm{yr}$ BP. According to the shore displacement curve compiled by Salomaa (1982) for Lauhanvuori, a mountain located roughly at the same isobase with Lake Ähtärinjärvi, Lake Ähtärinjärvi was isolated in about 9900 to $9800 \mathrm{cal}$ yr BP. The original threshold altitude of the first outlet river across the modern Suomenselkä watershed is at present $157 \mathrm{~m}$ a.s.l.

It can be assumed that the events associated with the post-glacial development of Lake Ähtärinjärvi, especially the shift of its outlet, can be detected in bottom sediments of the old outlet channel and Lake Ouluvesi, into which the new outlet drains. Consequently, these two sites were chosen for the sediment sampling. As the present level of Lake Ähtärinjärvi is close to the altitude of the old outlet channel in 


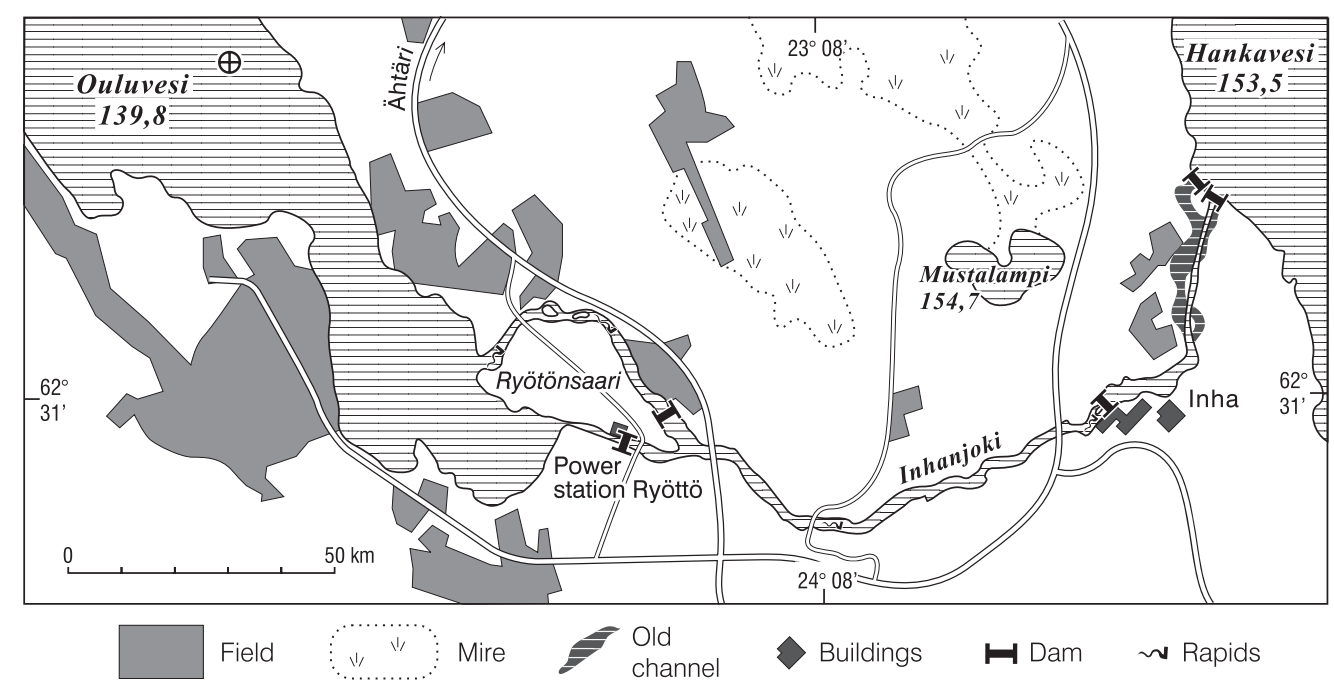

Fig. 2. A map of the region of the modern outlet channel. A sediment core was obtained from Lake Ouluvesi, from a location indicated with a cross.

the north, the development history of the lake does not include rapid and significant lowerings of the water level and it is unlikely that the shift of the outlet would be detectable in the bottom sediments of the lake. Especially in the old, paludified outlet channels the drying up of the channel can be observed as a sharp transition from coarse, fluvial gravel into limnic gyttja and, subsequently, into peat as the water flow in the channel ceased (Tikkanen, 1995; Tikkanen \& Seppä, 2001; Tikkanen \& Ruth, 2003).

The sediment samples from the old outlet channel and Lake Ouluvesi were taken through the ice with a Russian peat sampler (Jowsey, 1966). The sampling site at shallow Lake Ouluvesi was chosen from a 4 $\mathrm{m}$ deep depression $900 \mathrm{~m}$ from the mouth of River Inhanjoki (Fig. 2). Loss-on-ignition (LOI) analyses were carried out in a laboratory in order to investigate the variability of the relative organic matter content of the sediment (Bengtsson \& Enell, 1986). Three AMS radiocarbon dates were obtained, and calibrated with CALIB 4.3 program. (Stuiver \& Reimer, 1998). The physiographical features of the old and modern outlet channel were observed in the field and on the maps. Sediment corings and high-precision levellings were carried out along the old outlet channel.

\section{Results}

\section{I. Poikkijoki - the old outlet channel}

At the northern end of Lake Ähtärinjärvi there is a narrow and partly paludified valley, where the water flows slowly towards the lake. In its southern part the valley widens into Perälampi, the northernmost part of Lake Ähtärinjärvi. On the northern side of Perälampi the gently winding channel is partly overgrown by vegetation, but there are also open water areas in the centre of the channel. This distinct palaeochannel, about 50 to $100 \mathrm{~m}$ in width, crosses over the Suomenselkä watershed at Livonlähde (Fig. 4). The gradient of the landscape is very gentle and the flow of water in the paludified channel is slow. The name of the channel south of the watershed is Poikkijoki and on its northern side Latojoki. The altitude of the watershed on the surface of the channel is about 156 $\mathrm{m}$ a.s.l., i.e. only about $1.5 \mathrm{~m}$ above the maximum regulation level of Lake Ähtärinjärvi and $2.5 \mathrm{~m}$ above the median regulation level of the lake. According to the precise levelling carried out in the channel in the 1940 s the thickness of the peat layer in the channel is 2-4 m (Vilkuna, 1951). At the watershed the channel is overgrown although there is water under the peat (Fig. 5a). Further north the channel becomes wid- 

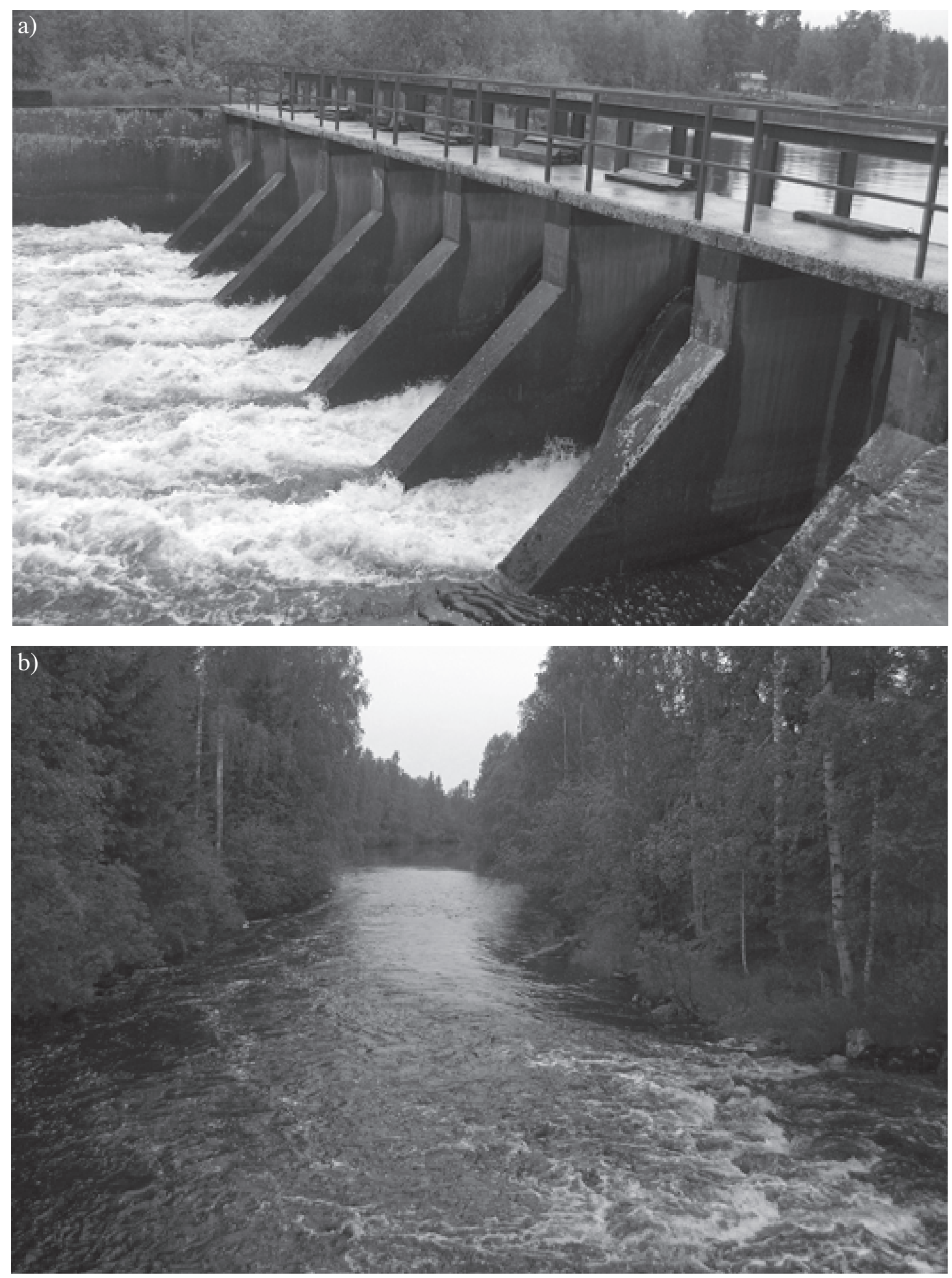

Fig. 3. a) A regulation dam at the opening of the modern outlet channel of the Ähtärinjärvi. b) The modern outlet channel, River Inhanjoki, flows into Lake Ouluvesi, about 13 m below the level of Lake Ähtärinjärvi. 


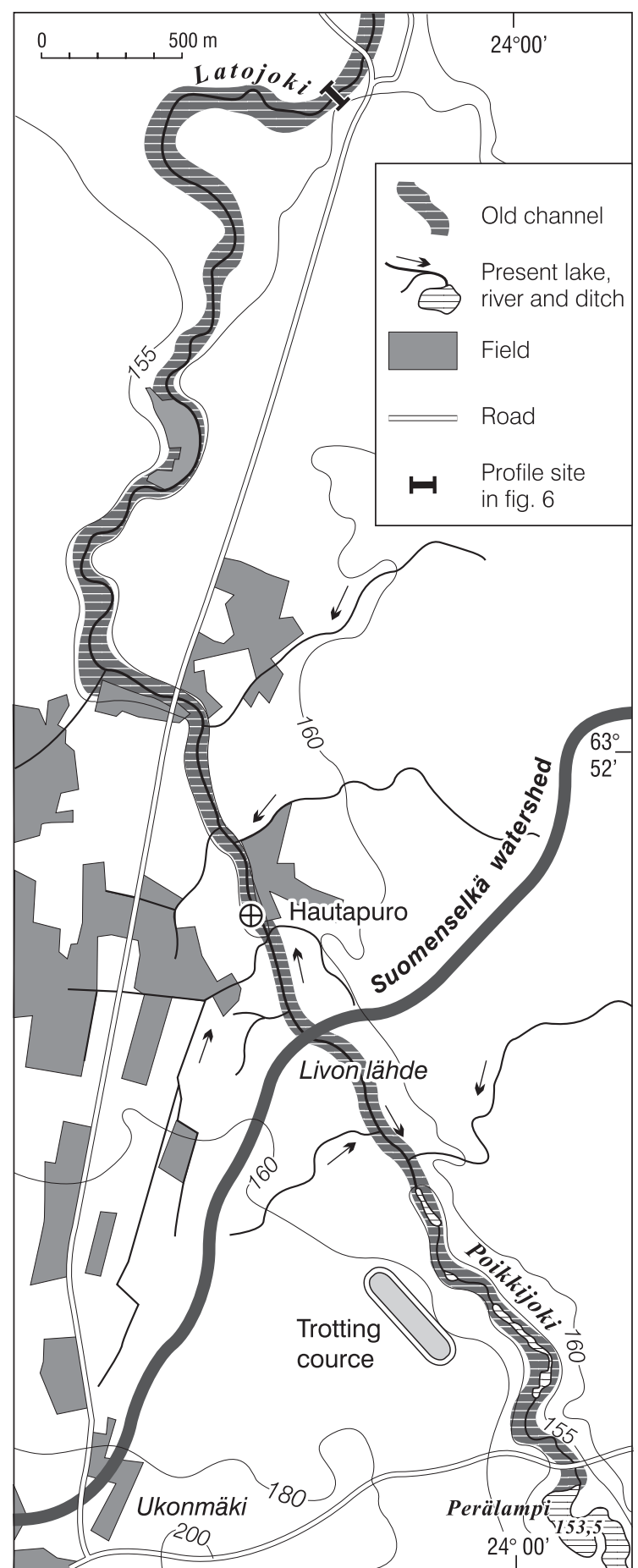

Fig. 4. An enlarged map showing the location of the old outlet channel crossing the modern Suomenselkä watershed. The sediment samples for dating the cessation of the flow in the channel were taken from the point marked with a cross (Hautapuro). er with a small rivulet in the centre (Fig. 5b). A profile measured across the channel about three kilometres north of the watershed shows that the width of the channel is about $70 \mathrm{~m}$ and the depth $5 \mathrm{~m}$ (Fig. 6). The bottom of the channel is paludified here as well, with a $1 \mathrm{~m}$ thick layer of peat and gyttja.

A $200 \mathrm{~cm}$ sediment sequence was sampled from the old outlet channel in Hautapuro, about $500 \mathrm{~m}$ south of the watershed. The water depth at the coring location was $50 \mathrm{~cm}$. The basal sediment at the coring site consists of gravel and sand, deposited by a highenergy flow, overlain by a sharp contact to a layer of clay-gyttja and gyttja (Fig. 7). The same sediment sequence was observed in five corings of the channel bottom. The thickness of the gyttja layer is $22 \mathrm{~cm}$, overlain by a $100 \mathrm{~cm}$ thick layer of peat. At a depth of $125 \mathrm{~cm}$ the content of sand and silt in the peat increases rapidly, apparently due to forest clearance and forest ditching.

Two radiocarbon datings were carried out from the contact of the gravel and gyttja layers. The distance between the two sampling sites was $5 \mathrm{~m}$. Both datings gave an identical age, $1480 \mathrm{cal} \mathrm{yr} \mathrm{BP} \mathrm{(Fig.} \mathrm{7,} \mathrm{Ta-}$ ble 1). The result shows that at least a continuous flow of water in the channel ceased at about $1500 \mathrm{cal}$ yr BP. As a result, gyttja started to accumulate in the channel and the channel margins became overgrown by telmatic vegetation.

\subsection{The sediment in Ouluvesi - evidence for a bifurcation}

River Inhanjoki, the present outlet channel of Lake Ähtärinjärvi, flows into Lake Ouluvesi, 13.7 m below the level of Lake Ähtärinjärvi. It is likely that the opening of a new river into a relatively small lake would have led to a change in the lake sediment quality, especially because in addition to River Inhanjoki, only one small river, Sappionjoki, drains into Lake Ouluvesi. The LOI analysis of the sediment core shows that the organic content of the core declines rapidly from $13-15 \%$ at $431 \mathrm{~cm}$ to about $7 \%$ at 420 $\mathrm{cm}$ (Fig. 6). Upwards from this level the sediment is charaterised by light silt bands. Although the LOI in- 

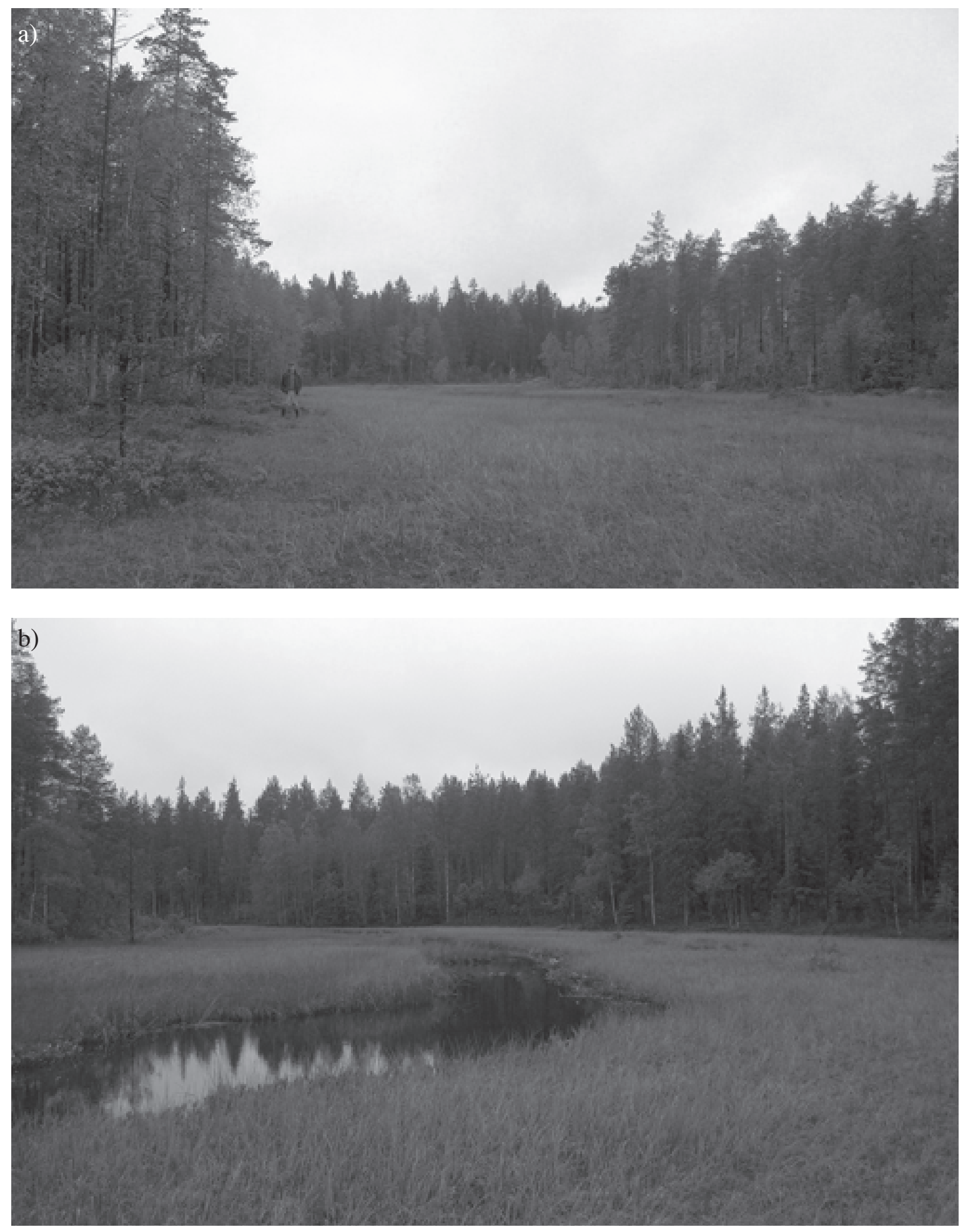

Fig. 5. a) The old outlet channel at the modern Suomenselkä watershed. The overgrown channel is exceptionally well-developed and distinct, probably due to the long duration of the water flow in the channel, from the isolation of the lake at about $9900 \mathrm{cal}$ yr BP until the cessation of the flow at I500 cal yr BP. b) The old outlet channel south of the watershed with open water in its centre. 


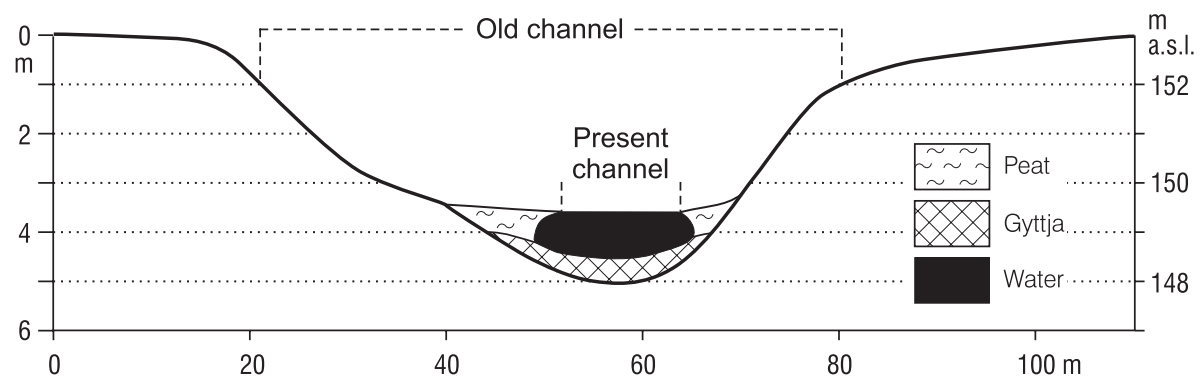

Fig. 6. A cross-sectional profile of the old outlet channel north of the modern Suomenselkä watershed. See Fig. 4 for the location of the profile site.
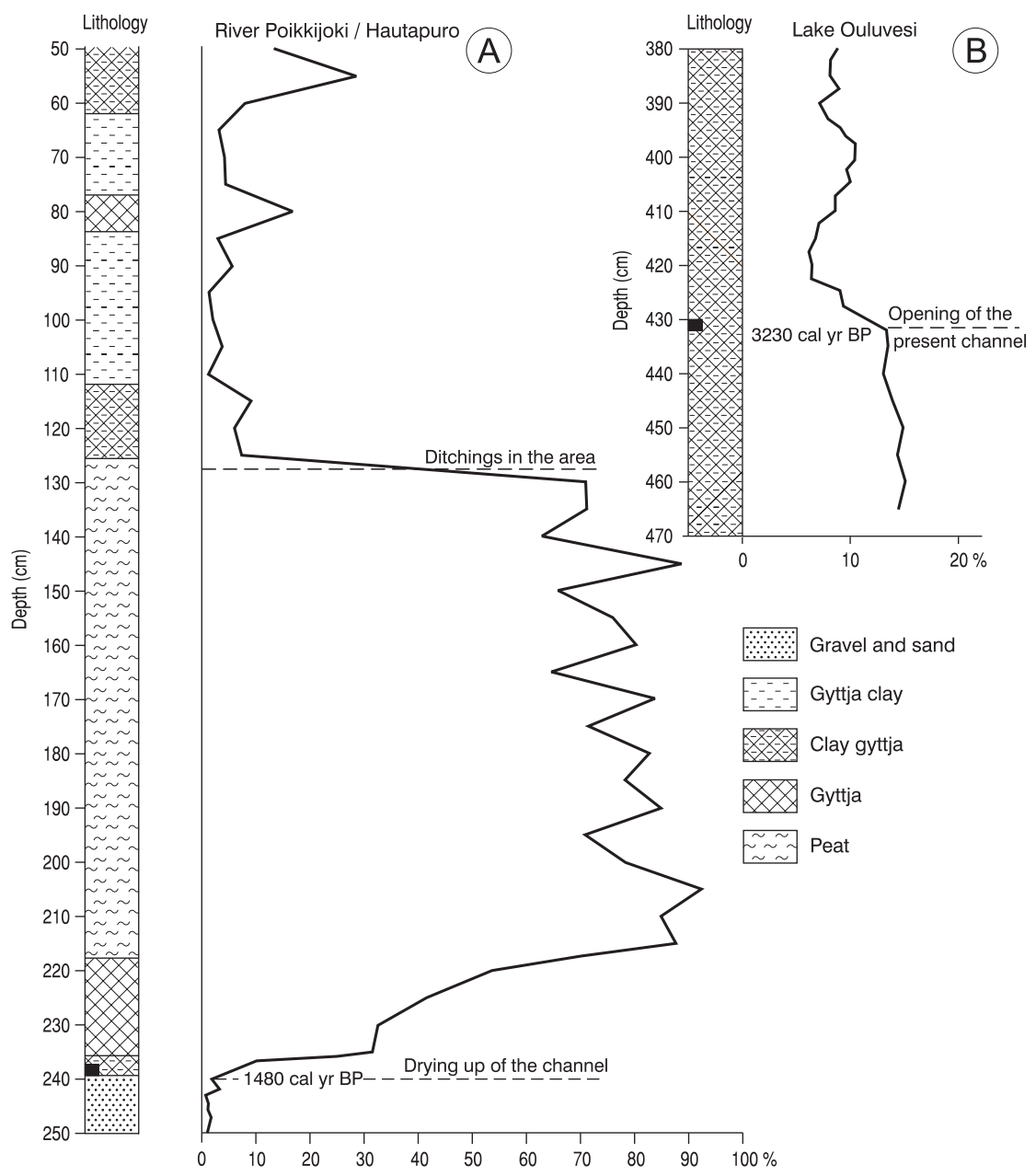

Fig. 7. a) A loss-on-ignition (LOI) profile from the old outlet channel. The cessation of the flow in the channel is indicated by a sedimentological change from gravel to peat. The peatlayer is overlain by sand, deposited due to forest ditching in the surroundings of the coring site. b) A LOI profile from Lake Ouluvesi, into which the modern outlet channel of Lake Ähtärinjärvi flows. The decrease of the LOI values from about $13 \%$ to $2-3 \%$ at 3230 cal yr BP indicates the opening of the modern outlet channel and the start of a bifurcative stage in the history of Lake Ähtärinjärvi. 
Table I. The radiocarbon dates. The dates were calibrated with CALIB 4.I program, applying a I0-sample smoothing. Samples Poz-10634 and Poz-10635 are from the old outlet channel and the sample Poz-10637 from Lake Ouluvesi. All samples were obtained from gyttja.

\begin{tabular}{|lll|}
\hline Lab no & Age ${ }^{14} \mathrm{C}$ & Age cal yr BP $(2 \mathrm{SD})$ \\
\hline Poz-10634 & $1600 \pm 30 \mathrm{BP}$ & $1480(1400-1554)$ \\
Poz-10635 & $1600 \pm 30 \mathrm{BP}$ & $1480(1400-1554)$ \\
Poz-10637 & $3035 \pm 35 \mathrm{BP}$ & $3230(3126-3338)$ \\
\hline
\end{tabular}

creases slightly upwards, it remains lower than before the change at $431 \mathrm{~cm}$. This indicates that a permanent change in the sedimentary conditions took place at level of $431 \mathrm{~cm}$ corresponding with a calibrated radiocarbon age $3200 \mathrm{cal} \mathrm{yr} \mathrm{BP} \mathrm{(Fig.} \mathrm{7,} \mathrm{Table} \mathrm{1).}$

It is probable that the sudden and permanent change in the bottom sediment of Lake Ouluvesi is related to the origin of the present outlet of Lake Ähtärinjärvi. The obtained radiocarbon age is, however, 1700 years older than that derived from the bottom of the old outlet channel in the north, suggesting that Lake Ähtärinjärvi had a bifurcative phase from $3200 \mathrm{cal}$ yr BP until the final drying up of the old outlet channel at $1500 \mathrm{cal} \mathrm{yr} \mathrm{BP}$.

\section{Discussion and conclusions}

Of the large Finnish lakes with uplift-induced outlet changes, Lake Ähtärinjärvi is probably the last one that has not been investigated so far. Another lake with no direct datings of the outlet changes is Lake Pielinen in eastern Finland, but indirect evidence gives relatively precise dates for the past outlet channels of the lake (Hyvärinen, 1966; Miettinen, 1996). The existence of an old outlet channel of Lake Ähtärinjärvi has been long known and drainage to the River Ähtävänjoki watercourse, draining into the Bothnian Gulf, has been postulated on the basis of the local names (Vilkuna, 1951). Similarly, the word "oulu" in the name of Lake Ouluvesi refers to a flood, which, according to Vilkuna (1951), indicates the origin of River Inhanjoki during the historical period. In contrast, suggestions that Lake Peränne, located downstream from Lake Ouluvesi, would have been the northernmost lake of the Ähtäri water course, and Lake Ouluvesi would have drained into Lake Ähtärinjärvi (Vilkuna, 1951; Ähtärinjärvi-projekti, 2004) cannot be true simply because the level of Lake Ouluvesi is $13 \mathrm{~m}$ below the level Lake Ähtärinjärvi.

On the basis of studies of local names, Vilkuna (1951) argues that the opening of the modern outlet would have taken place some time during the medieval time or in the 16th century, and in any case not earlier than the local lakes and rivers were named by the local people. Vilkuna (1951) further postulates that the argument for the relatively recent date for the opening of the new outlet is supported by the fact that the northern threshold is only over $1 \mathrm{~m}$ above the level of the Lake Ähtärinjärvi, so that during the great floods, such as the one that took place in 1899 (Hyvärinen et al., 1998) a flow northwards over the modern watershed may have taken place. However, since the onset of the hydrological observations of the Lake Ähtärinjärvi in 1911 no overflow in the old outlet channel has taken place (Fig. 8).

According to our results, the drying up of the old outlet channel took place at $1500 \mathrm{cal} \mathrm{yr} \mathrm{BP,} \mathrm{about}$ 1000 years earlier than assumed by Vilkuna (1951). As an identical age was obtained from two separate datings, this age can be deemed precise and reliable. A further assessment of the reliability of the radiocarbon dates can be carried out on the basis on modern differences in the land uplift rates between the modern outlet and the threshold of the old outlet channel in the north. The gradient vs. time curve for $1500 \mathrm{cal} \mathrm{yr}$ $\mathrm{BP}$ indicates that since $1500 \mathrm{cal} \mathrm{yr} \mathrm{BP}$ the old threshold has risen $80 \mathrm{~cm}$ in relation to the threshold of the modern outlet (Saarnisto, 1971; Tikkanen, 1995) (Fig. 9). This corresponds well with the altitude difference between the present level of Lake Ähtärinjärvi and the level of the bottom of the old outlet channel at the threshold. The obtained age $1500 \mathrm{cal} \mathrm{yr} \mathrm{BP} \mathrm{for}$ the drying up of the old outlet channel is therefore well supported.

The rate of tilting of the lake supports also the reconstructed bifurcation of Lake Ähtärinjärvi from 3200 to $1500 \mathrm{cal} \mathrm{yr} \mathrm{BP.} \mathrm{The} \mathrm{tilting} \mathrm{during} 3200$ years 


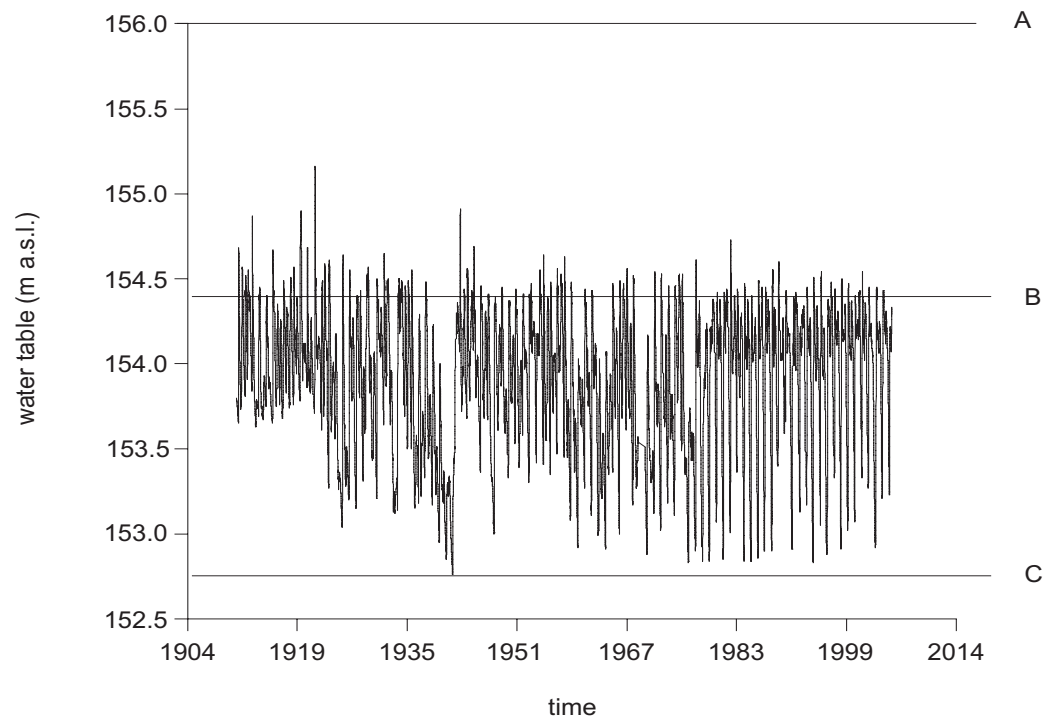

Fig. 8. The water table variations of Lake Ähtärinjärvi during the hydrological observation period 1911 - 200I. The maximum regulation limit at $154.4 \mathrm{I} \mathrm{m} \mathrm{(B)} \mathrm{and} \mathrm{the} \mathrm{minimum}$ regulation limit at $152.70 \mathrm{~m}$ (C) are indicated by the lines. The line $A$ shows the approximate threshold altitude (I56.0 $\mathrm{m}$ ) of the old outlet channel in the north; during the highest observed flood in 1922 the water level of the lake remained about $0.7 \mathrm{~m}$ below the old threshold in the north. has caused a $2 \mathrm{~m}$ difference between the modern outlet and the threshold of the old drainage channel. As the water depth in the old channel during the floods probably was over 2 metres, it is likely that the water level of Lake Ähtärinjärvi crossed the lowest threshold in the south that led to the opening of River Inhanjoki. The genesis of the new outlet did not, however, cause rapid erosion of the new outlet channel and subsequent rapid lowering of the lake level, because the soil of the River Inhanjoki threshold is stony and compact till. Slow and minor erosion is reflected by the shallowness of the modern outlet channel over the threshold before the canalising.

It is therefore likely that Lake Ähtärinjärvi had a 1700-year long bifurcative phase during which the drainage in the old outlet channel gradually decreased while it increased in the new outlet of River Inhanjoki. Bifurcations have been earlier observed in the post-glacial histories of some Finnish lakes (Hellaakoski, 1928; Saarnisto, 1970; Heikkinen \& Kurimo, 1977). For example, the Puula lake group in central Finland had a bifurcation of about 2000 years during the shift of the outlet (Tikkanen, 1995). Especially when the new outlet has been formed on stony till or rocky landscape, it has not caused a significant lowering of the lake level, providing suitable conditions for a long bifurcation (Hellaakoski, 1928; Saarnisto, 1970; Heikkinen \& Kurimo, 1977; Tikkanen, 1995), whereas an opening of a new outlet over fluvioglacial terrain has led to swift erosion of the channel and rapid lowering of the lake level (Saarnisto, 1971a; Vesajoki, 1980; Ristaniemi, 1987). Bifurcation has taken place also in the post-glacial development of some rivers in Finland (Tikkanen \& Ruth, 2003) and complicated bifurcations are characteristic of some rivers particularly on the coast of the Bothnian Bay (Kuusisto, 1984).

Although the increase of the drainage through the River Inhanjoki has been gradual, associated with the gradual tilting of the lake system, the sudden sedimentological change in the bottom sediment of the old outlet channel indicates a rapid cessation of the drainage at $1500 \mathrm{cal}$ yr BP. Had there been sporadic drainage in the channel during the floods in the lake, the sediment would contain layers of fluvial sediment, as has been observed in the context of a gradual change of the channel of River Vantaanjoki in southern Finland (Tikkanen and Ruth, 2003). The reason for the abrupt cessation of the flow can be a sudden increase of the drainage of River Inhanjoki, possibly due to the widening of the outlet over the threshold. Before the construction of the modern regulation dam, the River Inhanjoki began as two branches divided by a small island (Fig. 2 ). It is possible that a major flood in the lake has widened the outlet and may have led to the formation of the other branch. 


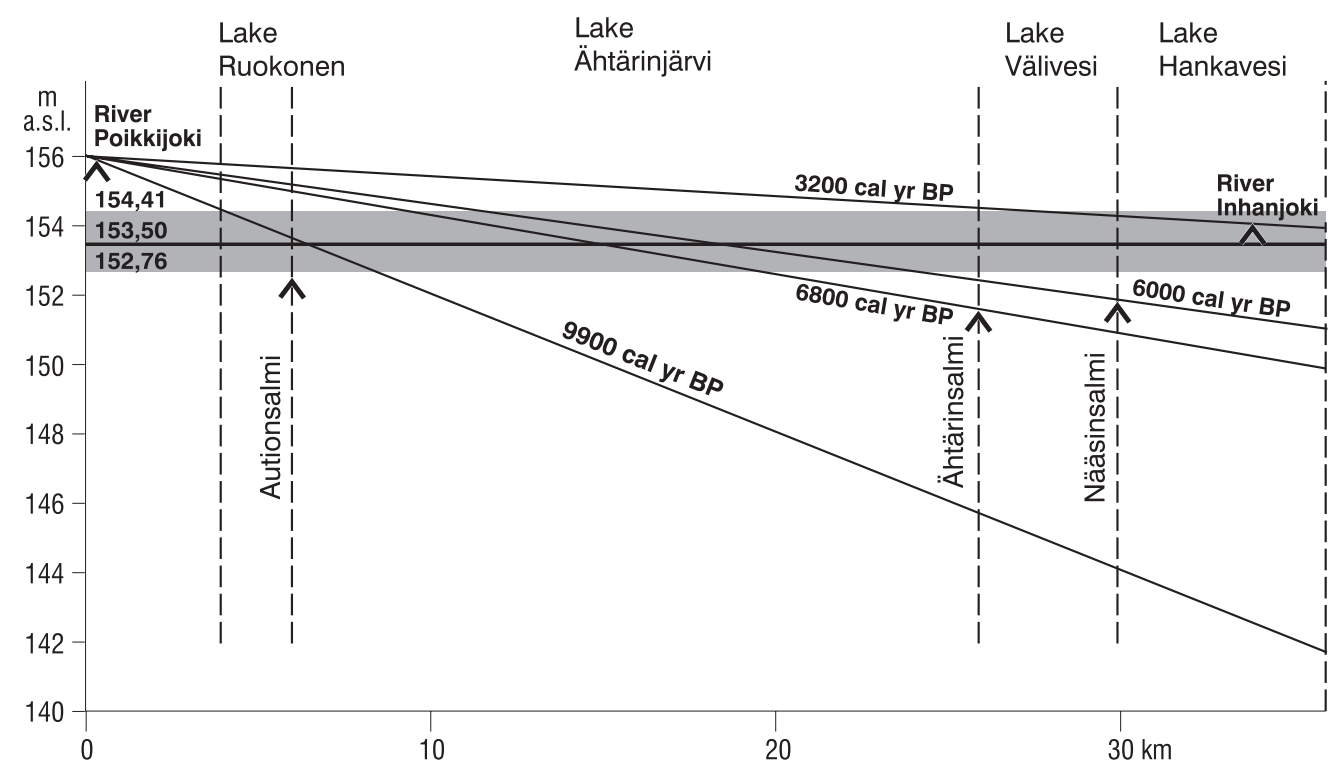

Fig. 9. A model for the post-glacial tilting of the Ähtärinjärvi lake system. The gradient of the tilting is based on the gradient vs. time diagrams compiled by Saarnisto (I97 Ib) and Tikkanen (I995). The model shows that the shoreline formed during the isolation at $9900 \mathrm{cal} \mathrm{yr} \mathrm{BP} \mathrm{has} \mathrm{now} \mathrm{a} \mathrm{gradient} \mathrm{of} 0.42 \mathrm{~m} / \mathrm{km}$. The tilting of the basin caused a transgression at the southern end of the lake. The transgression reached the level of the threshold of Lake Välive-

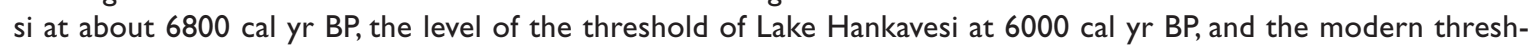
old at Inha at $3200 \mathrm{cal} \mathrm{yr} \mathrm{BP.}$

The two sub-basins of Lake Ähtärinjärvi, Lake Hankavesi and Lake Välivesi, which are now at the same level as Lake Ähtärinjärvi proper, were separate lakes during the early Holocene. The tilting of the shoreline of Lake Ähtärinjärvi formed at 9900 cal yr BP, during the isolation of the lake, can be reconstructed using the gradient vs. time curve showing the tilting of the past shoreline as a function of time. The reconstruction shows that the level of Lake Välivesi was about $6.0 \mathrm{~m}$ higher and Lake Hankavesi was about $7.5 \mathrm{~m}$ higher level than the level of Lake Ähtärinjärvi proper, but as the tilting of the lake system led to a transgression in the southern part of the lake system, Lake Välivesi was brought to the same level as Lake Ähtärinjärvi at $6800 \mathrm{cal}$ yr BP and Lake Hankavesi at $6000 \mathrm{cal} \mathrm{yr} \mathrm{BP} \mathrm{(Fig.} \mathrm{9).} \mathrm{The} \mathrm{separate}$ histories of the two southern sub-basins are still reflected in the nature of the straits between the basins, being typically narrow and river-like. A similar transgression has characterised many of the large lakes in central Finland, as reflected by findings of peat and wood submerged in over $20 \mathrm{~m}$ of water in the south- ern part of Lake Saimaa, the largest Finnish lake (Pajunen, 2005). An opposite process has taken place at Lake Ruokonen, the small, northernmost sub-basin of Lake Ähtärinjärvi, where the regression that followed the opening of River Inhanjoki has resulted in change from a wide strait to a river-like channel with a water depth of under $2 \mathrm{~m}$.

In conclusion, the new results show that (1) after its isolation at about $9900 \mathrm{cal}$ yr BP Lake Ähtärinjärvi drained to the north, via River Ähtävänjoki to the Bothnian Bay. Lake Hankavesi and Lake Välivesi, the two southern sub-basins of Lake Ähtärinjärvi, were at first at a higher level than Lake Ähtärinjärvi proper, the northernmost sub-basin of the whole lake system, but the tilting of the landscape and the subsequent transgression brought the sub-basin to the same level. (2) The transgression finally caused an opening of a new outlet channel, River Inhanjoki, in the southern part of the lake system at about $3200 \mathrm{cal}$ yr BP. The old outlet channel in the north dried up abruptly at about $1500 \mathrm{cal}$ yr BP. It therefore functioned as the outlet of the lake for about 8400 years, which led to 
the formation of one of the most conspicuous palaeochannels in Finland. The threshold of River Inhanjoki consists of stony till and the new outlet has not been able to erode a deep channel. (3) Lake Ähtärinjärvi had therefore an about 1700 year-long period of bifurcation during which the drainage through the River Inhanjoki increased and gradually decreased in the old outlet channel. Since the cessation of the flow in the old outlet channel at $1500 \mathrm{cal} \mathrm{yr} \mathrm{BP,} 240 \mathrm{~cm}$ of sediment has accumulated on the bottom of the channel.

\section{References}

Aario, R., 1967. Development of ancient Lake Päijänne and the history of the surrounding forests. Annales Academiæ Fennicx A III, 1-81.

Balling, N., 1980. The land uplift in Fennoscandia. Gravity field anomalies and isostasy. In: Mörner, N.-A. (ed.) Earth Rheology, Isostasy and Eustasy. John Wiley \& Sons, London-New York, p. 297-321.

Bengtsson, L. \& Enell, M., 1986. Chemical analysis. In: Berglund, B. (ed.) Handbook of Holocene Palaeoecology and Palaeohydrology John Wiley, Chichester, p. 423451.

Björck, S., 1995. A review of the history of the Baltic Sea, 13.0-8.0 ka BP. Quaternary International 27, 19-40.

Donner, J., 1995. The Quaternary History of Scandinavia. World and Regional Geology 7. Cambridge University Press, Cambridge, 200 p.

Ekholm, M., 1993. Suomen vesistöalueet. Vesi- ja ympäristöhallinnon julkaisuja A 126, 166 p.

Eronen, M., 1990. Itämeren kehitys. In: Alalammi, P. (ed.): Atlas of Finland, folio 123-126, Geology,. National Board of Survey \& Geographical Society of Finland, Helsinki, p. 15-19.

Eronen, M., 2005. Land uplift: virgin land from the sea. In: Seppälä, M. (ed.). The physical geography of Fennoscandia. Oxford University Press, Oxford, p. 17-34.

Heikkinen, O. \& Kurimo, H., 1977. The postglacial history of Kitkajärvi, North-eastern Finland, as indicated by trend-surface analysis and radiocarbon dating. Fennia 153,1-32.

Hellaakoski, A., 1928. Puulan järviryhmän kehityshistoria. (Referat: Die Entwiclungsgeschichte der Puula-Seengruppe). Fennia 43, 1-122.

Hyvärinen, H., 1966. Studies on the late-Quaternary history of Pielis-Karelia, eastern Finland. Commentationes Biologicae, Societas Scientiarum Fennica 29 (4), 1-72.

Hyvärinen, V., Kajander, J., Kuusisto, E., Seuna, P., Soveri, J., Malinen, R. \& Ferin-Westerlund (Westerholm), P., 1998. 90 Years of Hydrology in Finland. The Hydrographical Bureau, Helsinki, 30 p.
Jowsey, P.C., 1966. An improved peat sampler. New Phytologist 65, 245-248.

Kuusisto, E., 1984. Suomen vesistöjen bifurkaatiot (The bifurcations of Finnish watercourses). Terra 96, 253261.

Miettinen, A., 1996. Pielisen jääjärven kehityshistoria (The history of Pielinen ice lake). Terra 108, 14-19.

Mörner, N.-A., 1980. Late Quaternary sea-level changes in north-western Europe: a synthesis. Geologiska Föreningens i Stockholm Förhandlingar 100, 381-400.

Pajunen, H., 2005. Ala-Saimaan sedimentaatioympäristön muuttuminen jääkauden jälkeen (Abstract: Early Holocene change in the sedimentation environment at lower Lake Saimaa). Terra 117, 33-46.

Raatikainen, M. \& Kuusisto, E., 1990. Suomen järvien lukumäärä ja pinta-ala (Abstract: The number and surface area of the lakes in Finland). Terra 102, 97-110.

Rainio, H. \& Johansson, P., 2004. Jäätikkö sulaa. In: Koivisto M. (ed.). Jääkaudet, WSOY, Helsinki, s. 69-86.

Ristaniemi, O., 1987. Itämeren korkein ranta ja Ancylusraja sekä Muinais-Päijänne Keski-Suomessa (The highest shore and Ancylus limit of the Baltic Sea and the Ancient Lake Päijänne in Central Finland). Turun yliopiston julkaisuja - Annales Universitatis Turkuensis C $56,1-102$.

Saarnisto, M., 1970. The Late Weichselian and Flandrian history of the Saimaa lake complex. Commentationes Physico-Mathematicae, Societas Scientiarum Fennica 37, 7-107.

Saarnisto, M., 1971a. The upper limit of the Flandrian transgression of Lake Päijänne. Commentationes Physico-Mathematicae, Societas Scientiarum Fennica 41, 149-170.

Saarnisto, M., 1971b. History of Finnish lakes and Lake Ladoga. Commentationes Physico-Mathematicae, Societas Scientiarum Fennicae 41, 371-388.

Saarnisto, M., 2000. Shoreline displacement and emergence of lake basins. In: Pajunen, H. (ed.). Carbon in Finnish lake sediments. Geological Survey of Finland, Special Paper 29, 25-34.

Salomaa, R., 1982. Post-glacial shoreline displacement in the Lauhanvuori area, western Finland. Annales Academiae Scientiarum Fennicae, Geologica- Geographica III A 134.

Siegert, M. J., Dowdeswell, J.A, Hald, M. \& Svendsen, J.I., 2001. Modelling the Eurasian Ice Sheet through a full (Weichselian) glacial cycle. Global and Planetary Change 31, 367-385.

Stuiver, M. \& Reimer, P., 1998. Extended ${ }^{14} \mathrm{C}$ data base and revised CALIB $3.2{ }^{14} \mathrm{C}$ age calibration program. Radiocarbon 35, 215-230.

Tikkanen, M., 1990. Suomen vesistöjen jääkauden jälkeinen kehitys (Postgalcial history of Finnish watercourses). Terra 102, 239-255.

Tikkanen, M., 1995. History of the Puula Lake Complex, Central Finland, and shifts in its outlet. Fennia 173, 1-32. 
Tikkanen, M., 2002. Long-term changes in lake and river systems in Finland. Fennia 180, 31-42.

Tikkanen, M. \& Seppä, H., 2001. Post-glacial history of Lake Näsijärvi, Finland, and the origin of the Tammerkoski Rapids. Fennia 199, 129-141.

Tikkanen, M. \& Oksanen, J., 2002. Late Weichselian and Holocene shore displacement history of the Baltic Sea in Finland. Fennia 180, 9-20.

Tikkanen, M. \& Ruth, O., 2003. Origins and development of the ancient outflow channel of the river Vantaanjoki, southern Finland, as indicated by fluvial sediments. Fennia $181,69-83$.

Tolvanen, V., 1924. Muinais-Näsijärvi. Terra 36, $208-$ 218.

Tolvanen, V., 1926. Itä-Suomen vesistön kehityshistoriaa. Suomen matkailijayhdistyksen vuosikirja.

Vesajoki, H., 1980. Pre- and post-drainage development of the shore morphology and stratigraphy of Lake Höytiäinen, eastern Finland. Publications of the University of Joensuu B II 13, 30 p.

Vilkuna, K., 1951. Ähtärin nimestä ja muinaisuudesta. Vanhaa Ähtäriä, Kyrönmaa VIII, Etelä-Pohjalaisen osakunnan Kotiseutujulkaisuja, s. 7-21.

Ähtärinjärvi-projekti, 2004. http:||www.ahtari.fi/279026. aspx. 